\title{
Abolition Of Forced Labour: Case Of Uzbekistan
}

\author{
${ }^{1}$ Odiljon Sulaymanov, ${ }^{2}$ Jurabek Rasulov \\ ${ }^{1}$ Doctor of Law, Department of International Law and Human Rights, Tashkent State University of Law, \\ Tashkent, Uzbekistan. \\ E-mail address: o.sulaymonov@tsul.uz \\ ${ }^{2}$ Lecturer, Department of International Law and Human Rights, \\ Tashkent State University of Law, Tashkent, Uzbekistan. \\ E-mail address: j.rasulov@tsul.uz
}

Article History:Received:11 January 2021; Accepted: 27 February 2021; Published online: 5 April 2021

\begin{abstract}
The article analyzes the legal problems in the implementation of international labour standards on the abolition of forced labour in the national legislation of the Republic of Uzbekistan. Fundamental documents of the International Labour Organization on the abolition of forced labour - the legal nature of the Forced Labour Convention No.29, 1930 and the the Abolition of Forced Labour Convention No.105, 1957, the content of national legislation on this issue. The practice of assimilation of the provisions of international agreements on labor issues, which are legally binding for Uzbekistan, into national legislation, the compliance of some issues regulated by the legislation of the Republic of Uzbekistan on labor relations with the norms of international documents has been studied. As a result of the study, conclusions were made on improving the legislation on labor, criminal and administrative liability, as well as amendments to Article 7 of the Labor Code, Article $148^{2}$ of the Criminal Code and Article 51 of the Code of Administrative Liability, the Law of the Republic of Uzbekistan "On Employment" and were some suggestions on the appropriateness of making additions. Recommendations were made to amend the national legislation to abolition of forced and compulsory labour in order to bring it in line with international standards. The formation of institutional mechanisms for countering forced labour in Uzbekistan was studied in three periods, the specifics of each period, the functions of the established mechanisms, and the effectiveness of their activities were analyzed. In particular, the tasks of the National Commission for combating human trafficking and forced labour, created by the Decree of the President of the Republic of Uzbekistan No. PD-5775 dated July 30, 2019, and the Institute of the National Rapporteur are set out.
\end{abstract}

Key words: forced labour, Uzbekistan, implementation, ILO, fundamental principle

\section{Introduction}

According to the International Labor Organization (ILO), today, in the world 40.3 million people are in modern slavery, including 24.9 in forced labour and 15.4 million in forced marriage. 1 in 4 victims of modern slavery are children [1. ILO and WFF, 2017]. Article 8.7 of the UN Global Agenda for Sustainable Development until 2030, adopted by the United Nations General Assembly, considers a number of tasks such as to take immediate and effective measures to eradicate forced labour, end modern slavery and human trafficking and secure the prohibition and elimination of the worst forms of child labour, including recruitment and use of child soldiers, and by 2025 end child labour in all its forms [2. ILO, 2017].

In contrast to other fundamental labour rights such as freedom of association or the elimination of child labour, forced labour is an issue area that has not received much scholarly attention so far. The efforts of the ILO to achieve the successive abolition of forced labour comprises setting relevant standards, supervising these, determining adequate behaviour in terms of the instruments, and finally the application and implementation of these in practice. [3. L.Thomas, 2011].

The two fundamental ILO conventions on the elimination of forced labour - the Forced Labour Convention No.29 of 1930 and the Abolition of Forced Labour Convention No.105 of 1957 - have played a fundamental role in shaping international labour standards. Later, the provisions of these conventions were reflected not only in many international and regional documents, but also in the domestic legislation of states.

The definition of "forced or compulsory labour" in international law was first given in the ILO Convention No.29 on Forced Labour, which has the following meaning: "Forced or compulsory labour shall mean all work or service which is exacted from any person under the menace of any penalty and for which the said person has not offered himself voluntarily" [4].

For the purposes of this Convention, the term "forced or compulsory labor" under Article 2 of ILO Convention No. 29 does not include: (a) any work or service exacted in virtue of compulsory military service laws for work of a purely military character; (b) any work or service which forms part of the normal civic obligations of the citizens of a fully self-governing country; (c) any work or service exacted from any person as a consequence of a conviction in a court of law, provided that the said work or service is carried out under the supervision and control of a public authority and that the said person is not hired to or placed at the disposal of private individuals, 
companies or associations; (d) any work or service exacted in cases of emergency, that is to say, in the event of war or of a calamity or threatened calamity, such as fire, flood, famine, earthquake, violent epidemic or epizootic diseases, invasion by animal, insect or vegetable pests, and in general any circumstance that would endanger the existence or the well-being of the whole or part of the population; (e) minor communal services of a kind which, being performed by the members of the community in the direct interest of the said community, can therefore be considered as normal civic obligations incumbent upon the members of the community, provided that the members of the community or their direct representatives shall have the right to be consulted in regard to the need for such services [4].

While ILO Convention No.29 prohibits the use of all forms of forced or compulsory labour with some exceptions, Convention No.105 on the Abolition of Forced Labour strictly prohibits the use of forced labour and calls on Member States to terminate it immediately in the following five cases: (a) as a means of political coercion or education or as a punishment for holding or expressing political views or views ideologically opposed to the established political, social or economic system; (b) as a method of mobilising and using labour for purposes of economic development; (c) as a means of labour discipline; (d) as a punishment for having participated in strikes; (e) as a means of racial, social, national or religious discrimination [5].

The above definition of forced or compulsory labour is based on four elements: work or service; any person; the non-voluntary nature of the work or service; the existence of a threat of punishment for the performance of the work.

A work or service element refers to any work, service or employment that exists in any activity, industry or sector, including the informal economy. The nature or legality of the employment relationship is therefore irrelevant. For example, while prostitution is illegal in some countries, it may still fall under the orbit of C.29. Domestic work is often not regulated by labour law; however, forced labour as defined in C.29 can take place in private households [6, B.Andrees, 2008].

By any person is understood an adult and a child, citizens and non-citizens, including migrants who do not have an official status in the country of arrival.

While the lack of consent to involuntary work can be described as the route into forced labour, the threat of a penalty represents the means of keeping a person in forced labour [3. L.Thomas, 2011]. At the same time, "the penalty need not be in the form of penal sanctions, but might take the form also of a loss of rights or privileges". [7. M.Kern, C.Sottas, 2003].

While international documents use the term "forced labour" in cases of the use of labour against the will of a person, with the application or threat of any punishment to him, the term "compulsory labour" also includes elements of coercion meaning the required work or services by the state in connection with the need to perform any work. In all normative legal acts adopted in Uzbekistan on the issues of forced labor and compulsory labor, the term "compulsory labor" (majburiy mehnat) is used as a single concept for any case of forced labour. Based on the use of these terms in the Uzbek language and the requirements of international standards, it is advisable to use the concepts of "forced labour" and "compulsory labour" in the legislation in accordance with its content.

\section{The Main Part}

Abolition of forced and compulsory labour in Uzbekistan: implementation of international labour standards

There are two main ways of interaction between national labour law and international labour standards: the implementation of international labour law norms into domestic law and the adoption of domestic labour legislation taking into account international labour standards. The first and most obvious way of the impact of international labour standards on domestic legislation is to implement them into domestic law [8. N. Lyutov, 2015].

As of January 1, 2021, the Republic of Uzbekistan has ratified 17 ILO conventions (including 8 fundamental conventions) and 1 protocol. These documents include the Forced Labour Convention No.29, the Abolition of Forced Labour Convention No.105, the Protocol of 2014 to the Forced Labour Convention (ratified by Uzbekistan on June 25, 2019, entered into force for Uzbekistan on September 16, 2020) as well as Worst Forms of Child Labour Convention No.182, and Minimum Age Convention No.138, which directly regulates the legal relationship between forced labour and child labour. Uzbekistan has also ratified international human rights instruments adopted within the framework of the United Nations - the International Covenant on Civil and Political Rights of 1966 and the International Covenant on Economic, Social and Cultural Rights. The report of T.Narbaeva, who took part in the 103rd session of the International Labour Conference as the head of the Uzbek delegation, shows how relevant the issue is for Uzbekistan. As she stated, "admittedly, ratification of the conventions does not mean that the problem is solved. Ratification of the Coventions is a 50 percent solution to the problem, and the rest is the implementation of international norms into national legislation, which is the first. Secondly and most importantly, we need to change the practice of law enforcement and the thinking of the population, especially farmers and employers" [9]. 
If the Preamble to the Constitution of the Republic of Uzbekistan states that this document was adopted in recognition of the supremacy of universally recognized rules of international law [10], Article 3 of the Law of the Republic of Uzbekistan "On International Agreements of the Republic of Uzbekistan" stipulates that "international agreements of the Republic of Uzbekistan are an integral part of the legal system of the Republic of Uzbekistan, along with universally recognized principles and norms of international law" [11].

Article 10 of the Labor Code of the Republic of Uzbekistan states that "if an international treaty of the Republic of Uzbekistan or a convention of the International Labour Organization, ratified by Uzbekistan, establishes preferential rules for workers in comparison with labour legislation or other regulations, the provisions of an international treaty or convention, as well as international treaties or the International Labour Organization is ratified by Uzbekistan, the provisions of the Convention can be applied even in cases where labor relations are not directly regulated by law" [12]. Accordingly, the provisions of international labour contracts can be directly applied on the territory of Uzbekistan. The incorporation of the provisions of an international treaty into domestic law can have both positive and negative consequences for the effective implementation of that treaty. In the history of the ILO, there have been many cases when states have ratified a convention and considered that their obligations under this convention have been fulfilled. The ILO's oversight bodies have noted since the 1930s that ratification alone is not sufficient for the effective implementation of conventions.

The practice of mastering the provisions of international agreements on labor issues, which are legally binding for Uzbekistan, is also relatively common. Many issues regulated by the legislation of Uzbekistan on labor relations are reflected in international documents. In its turn, such internal norms have been adopted taking into account this or that international labor standard. It should be noted that it is not always possible to determine exactly what factors influenced the interpretation of national legislation in one way or another: internal reasons or the existence of an international document with a similar content in the field of labor.

This article is textually similar to the provisions of the two fundamental ILO conventions on the subject: Forced Labour Convention No.29 and Abolition of Forced Labour Convention No.105, but does not correspond exactly to their content. It is clear that the text of these conventions has been mastered in the definition of the concept of forced labour in the Labor Code and in the list of exceptions where such labor is not considered. The definition of forced labour in Article 7 of the Labor Code, which has been copied from the text of the conventions, is defined as "forced labour meaning the performance of work by threatening to impose any punishment (including as a means of maintaining labor discipline)" [12].

The application of ILO conventions and the prohibition of forced labor in the Labor Code of the Republic of Uzbekistan is also incompatible. We can observe differences in the application of forced labour to labor relations. Despite the fact that forced labour is prohibited under Article 7 of the Labor Code of the Republic of Uzbekistan, it is natural that the application of this Code to legal relations that are not labor relations is questionable. The problem is that the assessment of forced labour as a legal relationship that is only subject to the regulation of labor law is often unfounded. The reason is here we are talking about illegal coercion of a person to do something against his will. If we interpret the content of the Labor Code in a limited way, an illogical situation may arise: coercion may not be considered "forced labour" under the Labor Code because the person has not entered into an employment relationship. Forced Labor Convention No.29 is unconditionally applicable to such cases, as no article of this Convention provides that it applies only to relations arising under an employment contract. In applying the concept of forced labor, national legislators have significantly modified the definition in Convention No.29, which has led to a serious lack of acceptance of the legal definition of forced labour. The element of "voluntary non-offer of services" has been dropped from the concept of forced labour established by international standards in national legislation. The absence of this element in the definition of forced labour does not allow for a legally correct interpretation of this definition. The 2007 General comments of the ILO Committee of Experts noted that voluntary refusal to offer services also occurs when migrant workers are forced to remain at the employer's disposal as a result of fraud, false promises and illegal retention of documents. Such actions are a clear violation of ILO Convention No.29, and the concept of forced labour adopted in the Labor Code of the Republic of Uzbekistan does not apply to them. Article 2, paragraph 2, of Convention No.29 on Forced Labour provides for cases that are not classified as "forced or compulsory labour," the list of which is almost identical to Article 7, paragraph 2, of the Labor Code. However, on the basis of a comparative analysis of these documents, we can observe that the norms of national legislation have significant shortcomings in this regard.

Any work or service required by force of the laws on compulsory military service under Article 29 of the Forced Labour Convention and applicable to work of a genuine military nature is to be excluded from the scope of the Convention and is not to be regarded as compulsory labor. The same norm is stated in Article 7 of the Labor Code as follows: "Work that must be performed under the laws on military or alternative service is not considered forced labour" [12].

In these two cases, the issue of national military legislation, in particular the Law of the Republic of Uzbekistan "On General Military Duty and Military Service", adopted in 2002, is related to the content of "topical military issues" referred to in the ILO Convention No.29 there is no legal assessment in other legislative acts on the procedure. In particular, Article 4 of this Law defines general military service as a separate type of public 
service for citizens of the Republic of Uzbekistan in the performance of general military service in the Armed Forces[13]. From this definition, it is not possible to determine exactly which cases fall into the real military category. In view of the fact that the Convention has been ratified by the Republic of Uzbekistan and its requirements are binding on the subjects of the national legal system, the legislation should clarify its content and strictly define the list of "actual military activities" to be performed under military or alternative service law will be [14. J.Rasulov, 2020]. Otherwise, it will be difficult to make a fair legal assessment of the violation of the rights and legitimate interests of citizens serving in the military in the practice of law enforcement. It is the duty of the serviceman to carry out the orders of the commander of the military unit, except for the execution of orders that are contrary to the law from the very beginning. It is difficult to imagine a serviceman refusing to obey a commander's orders when he is involved in non-military work, such as building construction. According to ILO Convention No.29 on Forced Labour, the involvement of military personnel in such work is not an exception to forced labour.

Subparagraphs (b) and (e) of paragraph 2 of Article 29 of Convention No.29 also contain cases that are not provided for by national legislation and are not considered forced labour: (b) any work or service which constitutes part of the ordinary civic duties of the citizens of a fully self-governing country; e) minor community services, i.e. work performed by members of the team for the direct benefit of the team and therefore considered to be normal civil duties of team members, provided that only members of the team or their direct representatives have the right to consult on the appropriateness of such work[4]. In these two cases, the main emphasis is on the fact that the performance of work by citizens of the country, which is a civic duty enshrined in law, is not considered forced labour. Obviously, in order to involve citizens in such activities, strict compliance with the requirements set out in ILO Convention No.29 is necessary.

Given the lack of a definition in the legislation of the Republic of Uzbekistan of the concept of "minor community services", the involvement of citizens in such activities may lead to a violation of their labor rights. This should be strengthened by making appropriate amendments to the Law on Employment. In this case, it is advisable to take into account the criteria set by the ILO Committee of Experts.

In this regard, it is important to apply the concept of "hasher" (community work collectively adopted in traditions) in our national legislation, to study the legal nature of the work and services carried out under this concept. The analysis of the legislation shows that today in the legislation of Uzbekistan such terms as "paid public works" and "hasher" are used. Meanwhile, the lack of a clear definition of the term "hashar" in the legislation can lead to problems in terms of respect for the rights of persons involved in such activities. Only some legislation sets out the requirements for organizing a hashar. In particular, the Resolution of the Cabinet of Ministers of the Republic of Uzbekistan dated May 10, 2018 No.349 "On additional measures to eliminate forced labour in the Republic of Uzbekistan" sets out the necessary conditions for the hashar. According to it, hashars can be obligatorily involved in all other types of public works, including construction and agricultural work, only on a voluntary basis, if there is an appropriate document from the President of the Republic of Uzbekistan or a resolution of the Cabinet of Ministers. Such official community work can be organized to carry out work on greening, beautification and landscaping without strict permission [15].

The Uzbek dictionary defines the word "hasher" as "voluntary, impartial participation of the majority in the performance of a task" [16]. As we can see, the concept of "hasher" means, first of all, the performance of any work on a voluntary basis. One of the most important elements of the definition of "forced labour" discussed in detail in the previous chapters is that the work or service is demanded against the will of the individual. Hence, the presence of a person's will is the most important factor in organizing a hashar. Forcing a person to participate in a hashar through the threat of any punishment is also a direct indication of the existence of the concept of "forced labour". Accordingly, it is important to develop a legal definition of the concept of "hasher" in national legislation. Based on the nature of social relations associated with the concept of hashar, the practice of applying this concept in the legislation, it is expedient to define this concept as follows:

"Hashar is work performed by a person on a voluntary basis, necessary for the needs of the community to which he belongs, including the labor community, in strict compliance with the rules of labor protection and safety".

It is known that under Article 29, paragraph 2, subparagraph (d) of Convention No.29, the performance of "any work or service exacted in cases of emergency, that is to say, in the event of war or of a calamity or threatened calamity, such as fire, flood, famine, earthquake, violent epidemic or epizootic diseases, invasion by animal, insect or vegetable pests, and in general any circumstance that would endanger the existence or the wellbeing of the whole or part of the population" [4] is not forced labour.

Some aspects of involving citizens in work or services in emergencies without their consent are partially established by the current legislation of the Republic of Uzbekistan. In particular, Article 12 of the Law of the Republic of Uzbekistan "On protection of the population and territories from natural and man-made emergencies" stipulates the involvement of citizens in self-government bodies in the elimination of the consequences of emergencies. In addition, Article 15 of the Law stipulates that citizens have the right to compensation and benefits for their participation in the elimination of emergencies, and Article 16 stipulates that citizens must assist in 
carrying out rescue and other urgent work, if necessary [17]. At the same time, the current legislation does not regulate the procedure for involving citizens in such activities, the categories of citizens who may be involved, the amount of guarantees and compensations, as well as other issues related to the labor rights of citizens in such circumstances.

In order to comply with international standards and harmonize national legislation with the involvement of persons in forced labor in emergency situations, it is advisable to include rules on the procedure for determining compensation and their amount in the Law of the Republic of Uzbekistan "On Employment" to ensure the protection of citizens' labor rights in such conditions.

The analysis of the norms of the Labor Code of the Republic of Uzbekistan regulating amendments to employment contracts revealed cases of non-compliance with international standards on the prohibition of forced labor in matters of temporary transfer to another job. It is important to reach a mutual agreement of the parties on all issues related to the amendment of the employment contract, regardless of whether the initiator is the employer or the employee. In this context, it is important that the exceptions to this rule be applied in legislation. According to the labor legislation (Article 95 of the Labor Code), it is allowed to temporarily transfer an employee to another job without his consent due to the necessity of production or termination [12]. In this case, there is an element of compulsory transfer of the employee to another job, which has the nature of production of the employer and does not go beyond the scope of his economic activity, which contradicts the principle of termination of forced labor. This situation does not fall within the scope of exceptions that are not considered forced labor under Article 29 of the Convention on Forced Labor, in particular in the context of emergencies. Under Convention No.29, the phrase "emergency" includes "war or disaster, or catastrophic events, such as fire, flood, famine, earthquake, severe epidemic or epizootic disease, pests, insects or parasites" cases of attack and situations that endanger or may endanger the life or stable living conditions of the general population or part of the population as a whole [12]. To eliminate this discrepancy in national legislation, it is proposed to amend the first part of Article 95 of the Labor Code as follows: "In the event of an emergency, an employee may be temporarily transferred to another job without his or her consent. In this case, the employee cannot be transferred to another job that does not correspond to his health".

Article 2 of ILO Convention No.29 provides a complete and strict list of jobs that are not considered forced labour, and exceptions not provided for in this list may not be established in national legislation. In this regard, researcher M.Makhamatov stated: "In our opinion, the Labor Code of the Republic of Uzbekistan contains a list of the most important norms in the field of labor relations. It should be noted that the definition of "work to be carried out in other cases provided for by law" in the list of cases included in the list of cases that are not considered forced labour in the Labor Code of the Republic of Uzbekistan does not meet the requirements of international standards. Therefore, Article 7 of the Labor Code, the second part of the ILO Convention No.29, Article 2, paragraph 2, is mutually exclusive [18, Makhamatov, 2019]. "Work or service" and "minor services" of the team, i.e. work performed by members of the team for the direct benefit of the team and therefore can be considered normal civic duties of team members" and it gives a chance to estimate the related issues objectively.

ILO Forced Labour (Indirect Compulsion) Recommendation No.35, 1930 is still considered as a relevant document. According to Part III of the Recommendation, "it is advisable to avoid any restrictions on the voluntary transfer of labour from one type of work to another or from one area to another, i.e. restrictions that may have indirect consequences forcing workers to work in certain sectors or areas" [19]. It is known that the institute of "permanent and temporary residence registration" in Uzbekistan provides for the notification of citizens of the country when they come to live or work in another region. However, such registration applies to citizens as their obligation. Residence registration is a complication of the former Soviet propiska system, in which citizens of the former USSR were not allowed to move freely, even within the country, without the permission of the administrative authorities. Article 6 of the Labor Code of the Republic of Uzbekistan states, "All citizens have equal opportunities to acquire and exercise labor rights. Any restrictions in the field of labor relations in relation to gender, age, race, nationality, language, social origin, property status and position, religion, beliefs, membership in public associations, as well as other aspects not related to the working capacity of employees and their work results or privileges are not allowed and are considered discriminatory" [12]. Any restrictions in the field of labor relations established by the labor legislation shall mean direct and indirect restrictions. The institution of registration at the place of residence, on the other hand, imposes an indirect restriction on labor relations and is considered one of the criteria for discrimination. This can be seen from the active use of the practice of refusing to hire on this criterion. The levels of economic development of the regions of the Republic of Uzbekistan differ significantly. Preventing internal labor migration by any means, including through the registration institution, is contrary to the requirements of ILO Recommendation No.35, which indirectly compels workers to work in their areas of residence. In addition, the institute has a negative impact on the effectiveness of measures to support employment, reducing the mobility of workers. In addition, this institute will lead to the persistence of sharp stratification of wages in different regions of the country. Article 37 of the Constitution of the Republic of Uzbekistan stipulates the prohibition of forced labour, except for the procedure for serving a sentence imposed by a court or in other cases provided by law[10]. Also, in accordance with the Law of the Republic of Uzbekistan 
"On Amendments and Addenda to Certain Legislative Acts of the Republic of Uzbekistan" No. ZRU-603, adopted on January 22, 2020, the Criminal Code and the Code of Administrative Offenses of the Republic of Uzbekistan relevant changes and additions were made [20]. These cases testify to the efforts to firmly implement international standards for the abolition of forced labour practices in national legislation.

At the same time, the norms of liability for the use of forced labor established by the legislation of the Republic of Uzbekistan on criminal and administrative liability do not fully reflect the provisions of international standards for the termination of forced labour.

It should be noted that this practice should be considered a serious crime as an important principle underlying efforts against forced labour. Article 25 of Convention No.29 states that "unlawful coercion or forced labour must be prosecuted and that each member of the Organization that has ratified the Convention must ensure the effective effect and strict observance of the sanctions established by law" [4]. That is, unlawful coercion must be punished as a crime, and member states must ensure that the penalties prescribed by law are indeed adequate and strictly enforced.

The legislation of the Republic of Uzbekistan stipulates liability for forced labour in Article 51 of the Code of Administrative Responsibility of the Republic of Uzbekistan and Article $148^{2}$ of the Criminal Code of the Republic of Uzbekistan, the disposition of which is as follows: "Any form of administrative coercion to work, except as provided by law". According to this legislation, administrative and criminal liability is established for such cases, respectively. This shows that the legislation of our country provides for liability only for "administrative involvement" in forced labour. This can create gaps in the definition of liability for most cases that are assessed as forced labour manifestations. It should be borne in mind that the use of forced labour in practice can also be committed by persons who do not have the authority to exert administrative influence.

While the Constitution of the Republic of Uzbekistan, the Labor Code and the Law on Employment provide for a broad interpretation of the principle of prohibition of forced labou, Article $148^{2}$ of the Criminal Code and Article 51 of the Code of Administrative Liability refer only to "administrative coercion". The opinion of the researcher U. Abdurakhmanov is that the provisions of the legislation on criminal and administrative liability do not cover all aspects of the concept of forced labour, fully reflects the responsibility not only of administrative bodies and officials [21. Abdurakhmanov, 2020], but also of any individuals and legal entities using this practice. It should be noted that the provision complies with the requirements of international standards. In this regard, special attention should be paid to the fact that the sectors of the economy where forced labor is applied are covered not only by officially recognized sectors, but also by informal sectors of the economy. This is because the use of forced labor in informal economic activities is very common.

In this regard, the removal of the word "administratively" from the provisions of Article $148^{2}$ of the Criminal Code of the Republic of Uzbekistan and Article 51 of the Code of Administrative Liability allows any person engaged in forced labor to be held criminally and administratively liable.

According to paragraph 4 of Resolution No.12 of the Plenum of the Supreme Court of the Republic of Uzbekistan of 24 November 2009 on Judicial Practice in Trafficking in Human Beings, human exploitation does not exist in all cases (for example, under contracts for construction, paid services, passenger transportation, freight forwarding, etc.) where human labor and services are used in accordance with labor and civil law. Paragraph 5 of the Resolution also states that "exploitation of a person means the use of other persons' prostitution or other forms of sexual exploitation, forced labour or services, slavery or slavery-like habits, a state of liberty or the removal of human organs or tissues". The decision of the Plenum states that the concept of "forced labour" means coercion to work by threatening to impose any punishment. Based on the role of the decision of the Plenum of the Supreme Court No.12 in the legal assessment of criminal acts related to human trafficking, harmonization of the definition of forced labour in this document with international labour standards is important in determining the correct qualification and liability for trafficking in human beings.

That is, an important issue is to establish liability for the complication of debt, which is characterized by the restriction of liberty, the use of physical force, the use of harmful and dangerous work.

At the same time, it is necessary to differentiate the types of penalties for such offenses, depending on the severity of the form of forced labour in administrative liability and criminal law, to determine the measures of liability for the use of forced labour. International standards for the abolition of forced labour, based on the analysis of foreign legislation, only administrative liability for violations of labor rights, harm to life and health, use of physical force against a person, threat of use of force, harm to health and life, restriction of liberty, documents it is expedient to establish criminal liability for relatively more severe forms, such as forced labour, due to the complication of the debt.

It is also proposed to make appropriate changes and additions to the legislation on the introduction of norms governing the recovery of material and moral damage caused by persons convicted by the court in the use of forced labour for victims of forced labor.

In this regard, it is expedient to include in the Labor Code of the Republic of Uzbekistan norms governing compensation for damage caused by the employer forcing an employee to work. It is proposed to supplement 
Chapter XII of the Labor Code with Article $187^{1}$ in the following edition, which provides for the establishment of material liability of the employer for the use of forced labor and the recovery of damages in court:

"Article $187^{1}$. Obligation of the employer to compensate for the damage caused as a result of forcing the employee to work.

Any damage (including non-pecuniary damage) caused to an employee as a result of forcing the employee to work by threatening to impose any fine against his or her will must be paid in full by the employer.

The provisions of the first part of this article also apply in cases where the employment relationship is not duly formalized through the fault of the employer and the employee is actually allowed to perform the employment relationship.

The issue of recovery and the amount of damages is considered in court and determined in accordance with the decision of the court.

\section{Institutional mechanisms for combating forced or compulsory labour: international instruments}

Effective organizational and legal measures have been taken in Uzbekistan to ensure the protection of human rights, in particular, the elimination of the worst forms of forced labor and child labor, and efforts in this direction continue. Reforms and changes in the abolition of forced labor are recognized by the international community.

Efforts to end forced labour require multi-faceted decisions that allow for the blurring of boundaries between ministries and agencies, as well as closer partnerships between social partners and civil society institutions. Clear national legal and political frameworks should form a comprehensive approach that takes into account all forms of forced labor, all aspects of the action required to end it, as well as the resources to effectively coordinate the activities of a large number of participants.

The current scale of forced labour suggests that non-compliance with relevant ILO documents is a common occurrence. However, cases involving forced labour indicate the complexity of the coercive process in practice. Amendments to existing legislation with the detection of non-compliance are not always sufficient, where additional efforts by government agencies are required to introduce mechanisms to combat forced labour in practice.

ILO Convention No.29 on Forced Labor does not provide specific recommendations on national policies and institutional frameworks that would help end forced labour. This gap in the Convention was later supplemented by the Protocol 2014 to the Convention on Forced Labor. Pursuant to Article 1, paragraph 2 of the Protocol, each member of the ILO is to develop a national policy and action plan for the effective prevention of forced labour in the long run [22]. At the same time, it is necessary to consult with employers and workers' organizations. The Protocol envisages the obligations of ILO members to take effective measures to prevent and eliminate the use of forced labour, and to provide legal protection for victims of such practices, including compensation for damages and the imposition of sanctions on offenders [22].

In accordance with the Protocol, national policies and action plans for the abolition of forced labour by Member States should include the following measures: to train and provide persons with the necessary information to prevent them from becoming victims of forced labour, in particular those belonging to a particularly vulnerable category; providing training and information to employers to prevent them from participating in forced labour practices; legislation on forced labour, including labor legislation, covers all workers and all sectors of the economy; strengthening labor inspection bodies and other organizations responsible for the implementation of legislation in this area; protection of individuals, especially labor migrants, from possible abuses and fraud in the recruitment and recruitment process; support the active efforts of the public and private sectors to prevent the risks associated with forced labour and to take appropriate response measures; identify the root causes and factors that increase the risks of forced labour [22].

The Protocol reaffirmed that the definition of forced labor is the same as in Convention No. 29, and that Article 1, paragraph 3, provides that the measures provided for in the Protocol shall include specific measures to combat trafficking in persons for the purpose of forced labour.

ILO Forced Labour (Supplementary Measures) Recommendation for 2014 (Recommendation No. 203) recommends the strengthening of competent authorities such as labor inspectorates, the judiciary and other institutional mechanisms dealing with compulsory labor issues in order to ensure the development, coordination, implementation, monitoring and evaluation of policies and action plans [23].

According to the Worst Forms of Child Labour Convention No.182, each member of the ILO develops and implements action plans to eliminate the worst forms of child labor as a matter of priority [24]. Such action plans will be developed and implemented in consultation with relevant government agencies and workers 'and employers' organizations, taking into account the views of other relevant groups as necessary.

In accordance with the Protocol to Prevent, Suppress and Punish Trafficking in Persons, Especially Women and Children, supplementing the United Nations Convention against Transnational Organized Crime, States shall adopt a comprehensive framework to prevent and combat trafficking in human beings, as well as to 
protect victims of trafficking, especially women and children, develop and adopt national policies, programs and other measures [25].

It is noted that special attention should be paid to labor inspections. A clearly defined national policy is the starting point for actions aimed at preventing forced labour and protecting its victims. At the same time, the main focus should be on identifying priority areas and activities, raising public awareness, strengthening institutional capacity.

\section{Formation of institutional mechanisms in Uzbekistan}

It is important to study the formation and development of institutional mechanisms for the abolition of forced labour in Uzbekistan in three periods.

The first period covers the period 1992-2007, which includes the ratification of international instruments on forced labour, the adoption of national legislation on the abolition of forced labour, and the establishment of mechanisms to ensure and monitor the implementation of these documents.

During this period, the Republic of Uzbekistan became a member of the ILO, ratified two main ILO conventions on forced labour - Nos.29 and 105, the Labor Code of the Republic of Uzbekistan, the Law on Employment, a number of laws regulating the activities of labor bodies documents were accepted. Also during this period, labor bodies, in particular, state labor inspections were established.

At the same time, during this period, the activities of special institutional structures for combating forced labour were not established, but this issue was considered one of the most common violations of labor legislation.

The second period covers the period 2008-2016, during which time international organizations have raised objections to the systematic use of forced labour and child labour in Uzbekistan, adopted national action plans to address existing problems, prevent forced labor and child labor, and exploited people and organized the formation of the first anti-trafficking institutions.

The Republic of Uzbekistan complements the ILO Worst Forms of Child Labour Convention, 1999 (No. 182), Minimum Age Convention, 1973 (No. 138), as well as the United Nations Convention against Transnational Organized Crime, ratified the Protocol to Prevent, Suppress and Punish Trafficking in Persons, Especially Women and Children, supplementing the United Nations Convention against Transnational Organized Crime. A number of by-laws were adopted, such as the Law of the Republic of Uzbekistan "On Combating Trafficking in Human Beings", Resolution No.207 "On Measures to Implement the Minimum Age Convention No.138 and Worst Forms of Child Labour Convention No.182", Resolution No.82 "On Additional Measures for the Implementation of the Worst Forms of Child Labour Convention No.182 in 2012-2013", Resolution No.132 "Conventions of the International Labour Organization (ILO) ratified by the Republic of Uzbekistan in 2014-2016" of the Cabinet of Ministers of the Republic of Uzbekistan. In addition, the Republican Interdepartmental Commission on Combating Trafficking in Human Beings and regional commissions and the Republican Rehabilitation Center for Assistance to Victims of Trafficking were established.

The Ministry of Labor and Social Protection of the Republic of Uzbekistan is tasked with coordinating the activities of ministries, departments and organizations to ensure the implementation of the obligations arising from the National Action Plan. Secondary school students in the cotton harvest will establish on-site monitoring to prevent the use of forced labour.

In 2013, a Coordinating Council on Child Labour was established in the Republic of Uzbekistan, which had the legal status of a public organization and consisted of representatives of the executive branch, trade unions, employers' associations, civil society institutions and international organizations. It should be noted that this structure is important in improving the state policy on the use and elimination of child labour in the country, amendments and additions to the legislation, the development of proposals for monitoring mechanisms for the use of child labour and mass seasonal monitoring with national and international experts.

The third period covers the period from 2017 to the present. During this period, a number of laws were adopted to effectively address the existing problems in the fight against forced labour and child labour, in particular, criminal sanctions for such forced labor practices were established, special institutional mechanisms for forced labor were formed, and cooperation with the ILO was renewed. Moreover, positive conclusions of international organizations on the effectiveness and results of measures to end forced labour and child labour began to be obtained.

In accordance with the Resolution of the Senate of the Oliy Majlis of the Republic of Uzbekistan dated October 4, 2017 No SQ-231-III "On strengthening measures to ensure the guaranteed labor rights of citizens in accordance with the laws of the Republic of Uzbekistan and international labor standards" has been introduced the institute of parliamentary control - the Parliamentary Commission on ensuring guaranteed labor rights of citizens, which provides for the implementation of comprehensive organizational and practical measures in this direction to prevent it.

In accordance with the Resolution of the Cabinet of Ministers of the Republic of Uzbekistan dated May 31, 2018 No 407 "On additional measures to implement the conventions of the International Labor Organization ratified by the Republic of Uzbekistan in 2018-2020" Republican interdepartmental commission was established. 
The main focus was on the preparation of reports of the Government of the Republic of Uzbekistan on the implementation of ILO conventions ratified by the Republic of Uzbekistan, study of ILO protocols, recommendations, declarations and other documents and preparation of proposals for their implementation in the national legal system, labour, employment and labour protection. It is important to organize the preparation of annual reviews, information and materials on the topics, as well as to bring them to the attention of various structures of the ILO, the UN [26].

According to the Resolution of the Cabinet of Ministers of the Republic of Uzbekistan dated July 3, 2019 No 553 “On Tripartite Commissions on Social and Labor Issues", the Republican Tripartite Commission on Social and Labour Affairs is to be formed. Its functions include promoting the implementation of basic principles and rights in the field of labor, the elimination of the worst forms of child labour and forced labour, non-discrimination, equal rights, equal opportunities and equal pay for equal work.

The Decree of the President of the Republic of Uzbekistan No.PD-5775 of July 30, 2019 “On additional measures to further improve the system of combating human trafficking and forced labour" on the abolition of forced labour has become important. According to the document, the Republican interagency commission on combating trafficking in human beings was reorganized as the National Commission for Combating human trafficking and forced labour. The decree also established the National Rapporteur Institute for Combating Trafficking in Human Beings and Forced Labour, which would report annually to the President on the situation in the fight against forced labor [27].

In accordance with this document, the issue of dissolving the Parliamentary Commission on Guaranteed Labour Rights and the Republican Interdepartmental Commission for the Implementation of Conventions of the International Labour Organization ratified by the Republic of Uzbekistan has been identified.

Currently there are three types of institutional mechanisms for combating and preventing forced labour in force in the Republic of Uzbekistan. The first type includes collegial mechanisms for combating forced labour referred to the National Commission for Combating Human Trafficking and Forced Labour, the Coordinating Council for Child Labour in the Republic of Uzbekistan and the Republican Tripartite Commission for Social and Labor Affairs. The main tasks of such structures are to coordinate the activities of state and territorial bodies, citizens' self-government bodies and non-governmental non-profit organizations in the field of combating forced labor, to organize the development and implementation of state programs and other programs in the field of forced labour, and to monitor their implementation, organization of effective international cooperation and joint action in the field of combating forced labour, as well as the collection, analysis and preparation of information in this area.

The second type of mechanisms involves labor authorities, particularly state labor inspectorates. The work of labor inspectorates is particularly important in preventing forced labour, ensuring the protection of the rights of its victims, and prosecuting those who use such practices. Important tasks for labor inspectorates based on international standards related to the activities of labor inspectorates to stop and prevent forced labour, Resolution of the Cabinet of Ministers of the Republic of Uzbekistan dated December 31, 2018 No.1066 "On measures to improve the activities of the Ministry of Employment and Labor Relations". In particular, the main tasks of labor inspections include the development and implementation of measures to prevent and eliminate forced labour, including through the prosecution of guilty officials in accordance with the law, together with the relevant ministries, departments and public organizations [28]. It also stipulates that labor inspectorates are to take legal regulatory measures in each case of forced labor and discrimination, and shall notify the relevant state authorities of violations [29]. According to the decision, the officials of the labor inspectorate were given the right to prepare documents on bringing the perpetrators to justice in accordance with the laws of the Republic of Uzbekistan, including criminal liability, and send them to law enforcement agencies and the courts.

Considering the importance of labor inspectorates in preventing and combating forced labour, protecting and restoring the rights of victims of such practices, transfer the functions of identifying and investigating violations of workers' rights related to forced labour to the State Labor Inspectorate, protecting the interests of forced labor, it is desirable to include provisions in legislation that provide for the possibility of filing a claim by the state labor inspectorate. In this term, it is effective to use the best practices of foreign countries in this regard.

The third type of mechanisms consists of civil society institutions - trade unions, public organizations, which deal with issues of combating forced labour. Trade unions participate in the protection of socio-economic rights and interests of employees, participate in the development of draft regulations and regulations in the field of technical regulation, participate in the development of state employment programs, protect the interests of employees in labor disputes, plays an important role in ensuring the protection of labor rights of employees of the Republic of Uzbekistan, exercising their rights, such as participation in the conclusion of international agreements relating to the socio-economic rights and interests of employees and monitoring their implementation. Trade unions also participate in tripartite negotiations as employee representatives based on the principle of tripartism in the development of international labour standards.

One of the positive measures in the fight against forced labour in the Republic of Uzbekistan is the establishment of a national monitoring system. In this regard, two types of monitoring systems are being 
implemented, mainly during the cotton harvest season. The first is monitoring by state labor inspectors to ensure that workers' labor rights are respected. While until 2019, the monitoring was carried out by the relevant State Labor Inspectors in each region, in 2019, in addition to the regional State Labor Inspectorates, a working group was established at the Ministry of Employment and Labor Relations of the Republic of Uzbekistan. In 2019, a total of 259 cases of forced labour were identified during the study, and according to Article 51 of the Code of Administrative Responsibility, $772 \mathrm{mln}$. fines in the amount of UZS were fixed. It was found that 141 cases of forced labour occurred during the cotton harvest [29].

According to the National Commission for Combating human trafficking and forced labour, 42 officials, including heads of organizations, the governor and his deputies, were prosecuted under Article 51 of the Code of Administrative Offenses for allowing forced labour during the 2020 cotton harvest. In 6 more cases, the relevant documents were submitted to the courts[30]. In addition, 61 cases of non-conclusion of employment contracts, 34 cases of non-creation of working conditions, 13 cases of non-performance of work duties, 17 cases of untimely payment of wages, cluster and farm managers were brought to administrative responsibility [31].

The national monitoring on the creation of conditions for workers in the 2019 cotton harvest and elimination of child labour and forced labour during the indicated period season has been conducted by the Trade Unions of Uzbekistan in cooperation with the National Commission for combating human trafficking and forced labour. In 2019, for the first time, the United States, European trade union centers, and a number of international trade union associations were invited to participate in the national monitoring process under the coordination of the International Trade Union Confederation (ITUC).

The second type of monitoring of forced labour cases is the study and monitoring of forced labour cases by ILO experts and human rights activists under the project "Third Party Monitoring". Since 2013, Uzbekistan has established a practice of monitoring child labour and forced labour with the participation of ILO experts. As a result of ILO monitoring in 2013, it was concluded that child labour was not systematically used in the cotton harvest. At the same time, it is acknowledged that there are cases of forced labour. Independent monitoring by the ILO in 2014-2018 concluded that the systematic use of child labour in Uzbekistan had been eliminated in recent years, and in 2019 the issue was no longer on the agenda. It is also noted that significant changes have been made in the fight against forced labour [32].

Today, it is advisable to take a number of measures to improve the mechanisms for combating forced labour. Cooperation between state labor inspectorates and law enforcement agencies should be strengthened to ensure the protection of the rights of persons involved in forced labour in areas and situations where labor relations are not established (for example, as a result of debt complications, domestic work, forced migration). This is because in the above-mentioned cases, as a result of the lack of formalization of labor relations, there is no possibility to apply sanctions by labor inspectorates, and it is effective to ensure cooperation with law enforcement agencies.

The creation of mechanisms to protect victims of forced labour is also an important issue in improving institutional mechanisms. At the same time, it is expedient to establish the right of victims of such practices to restore their violated rights, to apply to the labor inspection bodies and the court for compensation for material and moral damage. It is also important to include in labor and civil law measures and measures to restore the rights of workers affected by forced labour, in particular, dismissal from forced labour or employment contracts, recovery of wages, compensation for non-pecuniary damage, confirmation of length of service for forced labour.

\section{Conclusion}

Significant positive measures have been taken in Uzbekistan over the past decade to implement international standards for the abolition of forced labor in the country's legislation, the provisions of international conventions and the recommendations of ILO oversight bodies. At present, Uzbekistan has ratified two fundamental ILO conventions on forced and compulsory labour, conventions on the elimination of the worst forms of child labour, and the President and the government have adopted relevant regulations to ensure their effective implementation.

At the same time, acknowledging that international legal standards on forced labour have a significant positive impact on the formation of national legislation, our legislators have not fully assessed the content and essence of international legal norms in the implementation of these standards in national legislation. The application of ILO conventions and the prohibition of forced labour in the Labor Code of the Republic of Uzbekistan is inconsistent. Legal relations related to the concept of forced labor are limited to the scope of labor law. The assessment of forced labor as a legal relationship that is subject only to the regulation of labor legislation is inconsistent with the provisions of international standards.

Criminal and administrative liability for illegal or forced labor, not only for "administrative coercion", but also for any illegal use of such practices, is designed to protect the rights of persons directly or indirectly involved in forced or compulsory labor, will be essential in an effective fight. It is also necessary to improve the legal framework and mechanisms for the protection of victims of forced labor, the restoration of violated rights, compensation for damages at the expense of offenders. 


\section{References}

1. Global estimates of modern slavery: forced labour and forced marriage //

https://www.ilo.org/wcmsp5/groups/public/---dgreports/---

dcomm/documents/publication/wcms_575479.pdf

2. Sustainable Development Goals: Trade Union Reference Manual on the 2030 Agenda for Sustainable Development, International Training Centre of the International Labour Organization, 2017, 2017 https://www.ilo.org/wcmsp5/groups/public/---ed_dialogue/--actrav/documents/publication/wcms_553141.pdf

3. Thomas, Lars. Steps to Compliance with International Labour Standards. The International Labour Organization (ILO) and the Abolition of Forced Labour. 1st Edition 2011. VS Verlag für Sozialwissenschaften | Springer Fachmedien Wiesbaden GmbH. 2011. -P.185.

4. C029 - Forced Labour Convention, 1930 (No. 29) // https://www.ilo.org/dyn/normlex/en/f?p=NORMLEXPUB:12100:0::NO:12100:P12100_INSTRUMEN T_ID:312174:NO

5. C105 - Abolition of Forced Labour Convention, 1957 (No. 105) // https://www.ilo.org/dyn/normlex/en/f?p=NORMLEXPUB:12100:0::NO:12100:P12100_INSTRUMEN T_ID:312250:NO

6. Andrees, Beate. Forced labour and human trafficking: A handbook for labour inspectors / Beate Andrees; International Labour Office. - Geneva: ILO, 2008. // https://www.ilo.org/wcmsp5/groups/public/--ed_norm/---declaration/documents/publication/wcms_097835.pdf

7. M. Kern and C. Sottas. Fundamental rights at work and international labour standards. / International labour standards. A global approach. Geneva, International Labour Office, 2002. // https://www.ilo.org/wcmsp5/groups/public/---ed_norm/--normes/documents/publication/wcms_087424.pdf

8. Лютов Н. Эффективность норм международного трудового права: монография. — Москва: Проспект, 2015. -C.174

9. http://www.unic.ru/event/2019-06-20/v-mire/tanzila-narbaeva-ratifitsirovat-konventsiyu-poldelaglavnoe-izmenit-otnoshen

10. Constitution of the Republic of Uzbekistan // https://www.lex.uz/docs/20596

11. Law of the Republic of Uzbekistan "On international agreements of the Republic of Uzbekistan" // https://lex.uz/docs/4193761

12. Labor Code of the Republic of Uzbekistan // https://www.lex.uz/docs/142859

13. Law of the Republic of Uzbekistan "On general military service and military service" // https://www.lex.uz/acts/78717

14. РасуЛов, Ж. А. (2020). ОБ ОСОБЕННОСТЯХ ПРИМЕНЕНИЯ ТЕРМИНА «ПРИНУДИТЕЛЬНЫЙ ТРУД» В НАЦИОНАЛЬНОМ ЗАКОНОДАТЕЛЬСТВЕ РЕСПУБЛИКИ УЗБЕКИСТАН И МЕЖДУНАРОДНЫХ ТРУДОВЫХ СТАНДАРТАХ. Review of law sciences, (1), 127-129. doi: 10.24412/2181-1148-2020-1-127-129

15. Resolution of the Cabinet of Ministers of the Republic of Uzbekistan dated May 10, 2018 No 349 "On additional measures to eliminate forced labor in the Republic of Uzbekistan" // https://www.lex.uz/docs/3730223

16. Ўзбек тилининг изохли луғати. А.Мадвалиев тахрири остида (2006-2008). Ўзбекистон Республикаси Фанлар академияси Алишер Навоий номидаги тил ва адабиёт институти. “Ўзбекистон миллий энциклопедияси" давлат илмий нашриёти. Тошкент. -Б.167

17. Law of the Republic of Uzbekistan "On protection of the population and territories from natural and man-made emergencies" // https://lex.uz/docs/68564\#69779

18. Махаматов М. Ўзбекистон Республикасининг Халқаро мехнат ташкилоти билан хамкорлигининг халқаро-хукуқий асослари. Юридик фанлар буййча фалсафа доктори (phd) диссертацияси автореферати. Тошкент. 2019. -Б.21.

19. R035 - Forced Labour (Indirect Compulsion) Recommendation, 1930 (No. 35) // https://www.ilo.org/dyn/normlex/en/f?p=NORMLEXPUB:12100:0::NO:12100:P12100_INSTRUMEN T_ID:312373:NO

20. Law of the Republic of Uzbekistan "On amendments and additions to some legislative acts of the Republic of Uzbekistan" // https://lex.uz/docs/4708436

21. Абдурахмонов У. Понятие принудительного труда: международные стандарты и законодательство Республики Узбекистан. Ўзбекистон Республикаси Бош прокуратураси ахборотномаси. 2 (42). 2020. - С.66

22. P029 - Protocol of 2014 to the Forced Labour Convention, $1930 / /$ https://www.ilo.org/dyn/normlex/en/f?p=NORMLEXPUB:12100:0::NO:12100:P12100_INSTRUMEN T_ID:3174672:NO 
23. R203 - Forced Labour (Supplementary Measures) Recommendation, 2014 (No. 203) https://www.ilo.org/dyn/normlex/en/f?p=NORMLEXPUB:12100:0::NO:12100:P12100_INSTRUMEN T_ID:3174688:NO

24. C182 - Worst Forms of Child Labour Convention, 1999 (No. 182) // https://www.ilo.org/dyn/normlex/en/f?p=NORMLEXPUB:12100:0::NO:12100:P12100_INSTRUMEN T_ID:312327:NO

25. Protocol to Prevent, Suppress and Punish Trafficking in Persons, Especially Women and Children, supplementing the United Nations Convention against Transnational Organized Crime // https://undocs.org/en/A/RES/55/25

26. Resolution of the Cabinet of Ministers of the Republic of Uzbekistan No. 407 "On additional measures to implement the conventions of the International Labour Organization ratified by the Republic of Uzbekistan in 2018-2020" // https://lex.uz/docs/3760764

27. Decree of the President of the Republic of Uzbekistan No. PD-5775 "On additional measures to further improve the system of combating human trafficking and forced labor" // https://lex.uz/docs/4616405

28. Resolution of the Cabinet of Ministers of the Republic of Uzbekistan dated December 31, 2018 No 1066 "On measures to improve the activities of the Ministry of Employment and Labor Relations of the Republic of Uzbekistan" // https://lex.uz/docs/4143044\#4144766

29. Official website of the Ministry of Employment and Labor Relations of the Republic of Uzbekistan https://mehnat.uz/uz/news/2019-year-compulsory-labor-review-

30. Official site of the Senate of the Oliy Majlis of the Republic of Uzbekistan http://senat.uz/uz/lists/view/2142

31. Official site of the Ministry of Employment and Labor Relations of the Republic of Uzbekistan // https://mehnat.uz/uz/news/discussion-for-the-compulsory-labor-of-the-season-cotton-garden-seedingseason-of-the-normal-meeting-of-the-national-commission -done

32. https://uz.sputniknews.ru/society/20181214/10263513/Prezident-Shavkat-Mirziev-vstretilsya-sgendirektorom-MOT.html 